\title{
TRAUMATIC LESIONS OF EUROPEAN MOLE Talpa europaea (Linnaeus, 1758) IN MULTISLICE COMPUTED TOMOGRAPHY. CASE STUDY
}

\section{ZMIANY POURAZOWE U KRETA EUROPEJSKIEGO Talpa europaea (Linnaeus, 1758) W WIELORZĘDOWEJ TOMOGRAFII KOMPUTEROWEJ. OPIS PRZYPADKÓW}

\author{
Department of Morphological Sciences, Warsaw University of Life Sciences, Poland \\ ${ }^{1}$ Virtual Reality Techniques Division, Institute of Micromechanics and Photonics, Warsaw University \\ of Technology, Poland \\ ${ }^{2}$ Department of Criminal Law and Criminal Procedure, University of Zielona Góra, Poland \\ 3II Department of Clinical Radiology, Medical University of Warsaw, Poland
}

\begin{abstract}
Streszczenie. Kreta europejskiego objęto w Polsce częściową ochroną gatunkową. Analizie poddano zmiany pourazowe u dwóch kretów. W tym celu użyto szesnastorzędowego tomografu komputerowego (CT), uzyskując obrazy w różnych projekcjach. Kret A doznał złamań żeber VII-XIII i łopatki po stronie lewej oraz VI, VIII, XIII żeber z prawej strony. Czaszka drugiego kreta miała wieloodłamowe włamania, a prawa obręcz barkowa uległa przemieszczeniu. Wymienione obrażenia spowodowały śmierć obu zwierząt. Uzyskane dane można w przyszłości użyć do analizy tkanki kostnej i miękkiej kreta europejskiego.
\end{abstract}

Key words: European mole, causes of death, computed tomography, legislation, traumatic lesions. Słowa kluczowe: kret europejski, przyczyny śmierci, tomografia komputerowa, ustawodawstwo, zmiany pourazowe.

\section{INTRODUCTION}

The changes happening in the awareness and consciousness of the 21st century society influenced the way of how the death of an animal is. Humans, placing themselves at the top of the evolutionary pyramid, slowly realize that they are only a piece of the ecosystem, a millions year old entirety that provides their survival. The European mole, which also constitutes a piece of that entirety, a species found widely across the whole Europe (Gorman and Stone 1990), is particularly cared of in Poland. In the past, moles were hunted across the country for their fur, what contributed to the severe reduction in their population in Poland. Today, the European mole is under partial species protection and categorised in the Least Concern (LC) group

Corresponding author - Adres do korespondencji: Małgorzata Ludwiniak, Department of Morphological Sciences, Warsaw University of Life Sciences, building 24, Nowoursynowska 279, 02-776 Warszawa, Poland, e-mail: malgorzataludwiniak@gmail.com 
(Amori et al. 2008). Killing those specimens within Polish territory, with few exceptions mentioned in Regulation of Minister of Environment of 6th October, 2014 on animal species protection (Rozporządzenie Ministra Środowiska z 6 października 2014 r.), like allotment gardens, horticulture, airport, is punishable by fine, community sentence or imprisonment for two years, and in case of cruelty to animals the punishment might be prolonged to 3 years of imprisonment. The court may also pronounce compensatory damage of PLN 500 (around EUR 120) up to PLN 100000 (almost EUR 24 000), for intended animal protection purpose. Despite those measures, the protected animals are still found dead. The causes of deaths of a widespread species, like above mentioned European mole, are verified rarely, what is inconsistent with state regulations. The problem, described in this article concerning moles, may be transferred from the mole to any animal from the list of protected animals.

The unique structure of the mole has been the subject of many researches for many years. The oldest reachable work concerning anatomy of a mole dates back to 19th century and describes the pectoral limb (Freeman 1886). The parasite fauna of the mole is also well known (Shimalov and Shimalov 2001). A few publications describe the adaptation of mole's cardiovascular system to its lifestyle, among others the structure of its hemoglobin and its function in its subterranean life (Jelkmann et al. 1981). In the year 2010 microscopic cornea structure of a mole had been analysed (Carmona et al. 2010). The last publications describe the mole carrier state of the Nova Hanta Virus, which was found in the organisms of the moles living within the territory of Poland (Gu et al. 2015). The analysis of academic literature indicates that there is lack of renewed publications, concerning normal and pathological anatomy of a mole, including computed tomography (CT).

In this publication, CT allowed to determine the cause of death of the two moles found within area of strict species protection. The results showed how the species protection is applied in practice.

\section{MATERIAL AND METHODS}

The bodies of the two European moles, marked $A$ and $B$, were found in the vicinity of allotment gardens and included into museum collection of the Warsaw Agricultural University (SGGW). After placing them in containers, they underwent image scans in order to analyse their injuries and determine the cause of their death. Therefore the helical scans were made using sixteenth-multislice computed tomograph GE LightSeed PRO16 in SP CSK in Warsaw. The scan was made accordingly with following parameters: exposure $22 \mathrm{mAs}$, exposure time $2.2 \mathrm{~s}$, layer thickness $0.625 \mathrm{~mm}, \mathrm{kVp} 140 \mathrm{kV}$, exposure time $-2161 \mathrm{~ms}$, HFS position. The data obtained was researched at various levels using DicomViewer (UniPacs Inc) and VolView3 (Kitware). The 3D image of the two moles were reconstructed with the use of VolView 3 (Kitware) - Fig. 1. 


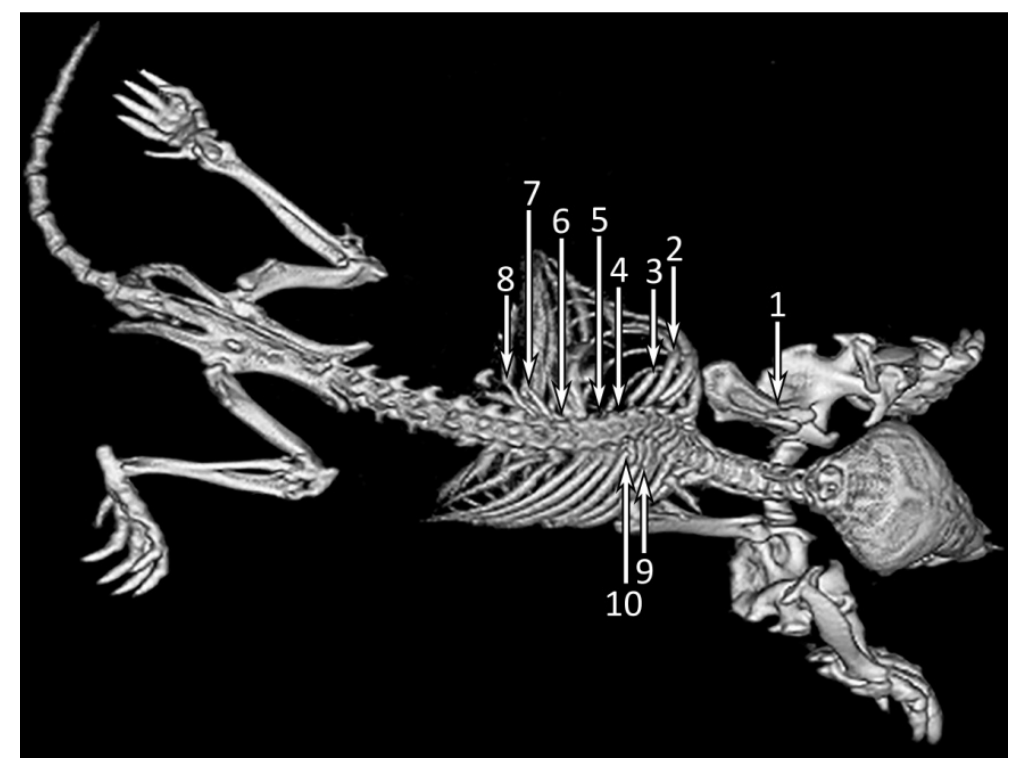

Fig. 1. 3D reconstruction of mole $A$ with visible dislocation fracture of the scapula (1), region of multiple rib fractures on the left side (2-8) and fractured right ribs VII-VIII (9-10)

Ryc. 1. Rekonstrukcja trójwymiarowa kreta A z widocznymi przemieszczonymi złamaniami łopatki (1); obszar licznych złamań żeber po lewej stronie (2-8) oraz złamania żeber po prawej stronie (9-10)

\section{RESULTS AND DISCUSSION}

The mole A had no fractures within the viscerocranium, the continuity of the spine was intact and in the beginning of the spine a few fractures of thoracic vertebra were found. Comminuted factures of VII-XIII ribs on the left side and fractured VII, VIII, XIII ribs on the right side were found in the chest. The complete fracture of the left scapula at the 2/3 of its length, displaced cranial, was also found within the shoulder girdle. The other bone structures showed no anomalies. It may be assumed that on the left and right side of the chest there was subcutaneous emphysema, spreaded in the area of broken ribs. The identification of larynx, trachea and oesophagus was possible, the outline of the liver was visible, as well as the intestinal loop, excessively filled with gas, what indicated progress of the putrefaction process. Regarding the skeletal structure of the mole $B$, it was possible to determine comminuted fractures of the calvaria of skull, displacement of the left shoulder girdle and fracture of the right scapula, also displaced. Regarding soft tissues, the heart $-10.27 \mathrm{~mm}$ long and $7.51 \mathrm{~mm}$ wide - was visible, as well as the outline of liver, lungs, the intestinal loop filled with fecal mass and finally muscle parts - core muscles as well as both pairs of pectoral and pelvic limbs. The identification of internal and external ear canals of proper structure was possible. The quality of the data obtained in CT scan did not enable the analysis of other areas of the head.

The determined injuries caused death of both moles and were most likely inflicted with a blunt instrument with malice aforethought. The area where the two moles were found might indicate that they were treated as pests and killed, regardless of their protection status in Poland.

As the above study shows, the modern image methodology might be effectively used as the source of evidence in proceedings against individuals intentionally abusing or taking lives of protected animal species, without the need to interference in the body. It might speed up the conduct of the procedure and ease the enforcement of existing law. So far, determining the 
cause of death has been usually performed using the traditional post-mortem techniques, as for example in the study concerning hawaiian geese (Work et al. 2015). Moreover, the threedimensional reconstructions will allow to localize the found injuries in space and better depiction of the animal condition. Similar reconstructions were performed for mice (Rusu et al. 2015), on the basis data obtained in magnetic resonance. The manners of generating threedimensional images of animals are developed constantly, as exemplified in publication describing new technique of reconstruction based on the data obtained in transillumination (Tran et al. 2014). Obstacles in analysing organs of the smallest animals, such as rodents can be omitted with application of modern medical imaging. Such methodology was applied by Wathen et al. (2013), using CT with contrast to scan soft tissues of murine. The pathological examination and non-invasive scanning techniques may solve problems frequently encountered in small mammal's clinical practice (Fig. 2).
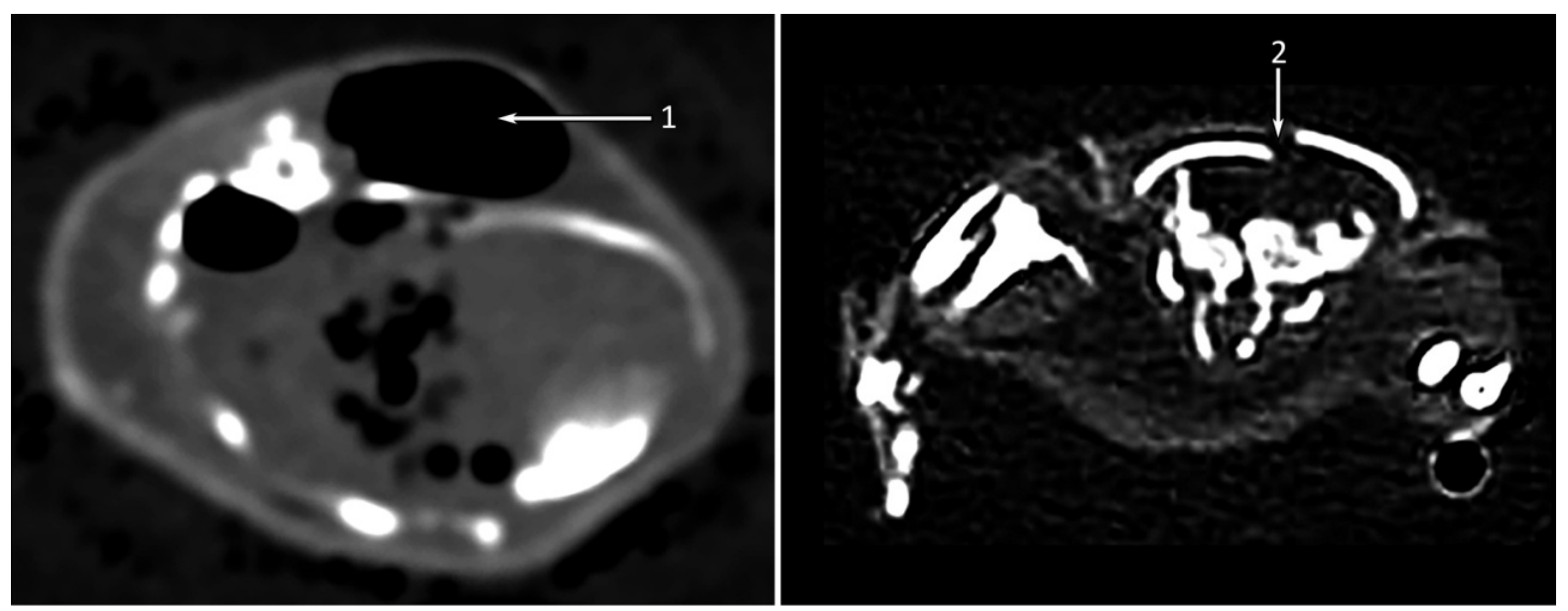

Fig. 2. Transverse CT image of mole $A$ with thoracic tissues affected by subcutaneous emphysema (1); transverse CT image of mole $B$ with depressed cranial fracture (2)

Ryc. 2. Obraz CT w projekcji poprzecznej kreta A z tkankami klatki piersiowej, z widoczną odmą podskórną (1); obraz CT w projekcji poprzecznej kreta B z włamaniami czaszki (2)

\section{CONCLUSIONS}

The results of this study shows utility of diagnostic imaging in veterinary forensic pathology, particularly its applicability duringproceedings as an evidence of intentional kill of threatened species. Additionally, it may be useful in mole imaging in the future.

\section{REFERENCES}

Amori G., Hutterer R., Mitsain G., Yigit N., Kryštufek B., Palomo L.J. 2008. Talpa europaea. The IUCN Red List of Threatened Species, http://dx.doi.org/10.2305/IUCN.UK.2008.RLTS.T41481A10462965.en, access: March 2016.

Carmona F.D., Ou J., Jiménez R., Collinson J.M. 2010. Development of the cornea of true moles (Talpidae): morphogenesis and expression of PAX6 and cytokeratins. J. Anat. 217, 488-500. 
Freeman R.A. 1986. Anatomy of the shoulder and upper arm of the mole (Talpa europaea). Part 2. J. Anat. Physiol. 20(200), 1-219.

Gorman M.L., Stone R.D. 1990. The natural history of moles. Ithaca, NY, Cornell University Press.

Gu S.H., Hejduk J., Markowski J., Markowski M., Liberski P.P., Yanagihara R. 2015. Whole-genome sequence of a novel hantavirus isolated from the European mole (Talpa europaea). Gen. Announc. 3, e00508-15.

Jelkmann W., Oberthür W., Kleinschmidt T., Braunitzer G. 1981. Adaptation of hemoglobin function to subterranean life in the mole, Talpa europaea. Respir Physiol. 46, 7-16.

Rozporządzenie Ministra Środowiska z dnia 6 października 2014 r. w sprawie ochrony gatunkowej zwierząt. DzU z 2014 r., nr 1348. [in Polish]

Rusu M., Golden T., Wang H., Gow A., Madabhushi A. 2015. Framework for 3D histologic reconstruction and fusion with in vivo MRI: Preliminary results of characterizing pulmonary inflammation in a mouse model. Med. Phys. 42, 4822.

Shimalov V.V., Shimalov V.T. 2001. Helminth fauna of the European mole (Talpa europaea Linnaeus, 1758) in Belorussian Polesie. Parasitol. Res. 87, 790-791.

Tran T.N., Yamamoto K., Namita T., Kato Y., Shimizu K. 2014. Three-dimensional transillumination image reconstruction for small animal with new scattering suppression technique. Biomed. Opt. Express. 5, 1321-35.

Wathen C.A., Foje N., Avermaete T.V., Miramontes B., Chapaman S.E., Sasser T.A., Kannan R., Gerstler S., Leevy W.M. 2013. In vivo X-Ray computed tomographic imaging of soft tissue with native, intravenous, or oral contrast. Sensors. 13, 6957-6980.

Work T.M., Dagenais J., Rameyer R., Breeden R. 2015. Mortality patterns in endangered hawaiian geese (Nene; Branta sandvicensis). J. Wildl Dis. 51, 688-95.

Abstract. The European mole is under partial species protection in Poland. The traumatic lesions of 2 moles have been analysed and a sixteenth-multislice computed tomography (CT) has been used to provide with images of various projections. Mole A had fractured VII-XIII ribs on the left side, and left scapula fractured with displacement, on the right side ribs VI, VIII and XIII fractured. The skull of mole B had comminuted fractures and the pectoral girdle was displaced. The above mentioned injuries caused death of both animals. The obtained data could be used in the future to analyse tissues of a mole. 
